\title{
Peranan social capital dalam memelihara keberlanjutan agribisnis jagung
}

\section{The role of social capital on nurturing of corn agribusiness sustainability}

\author{
Jajat Sudrajat $^{1}$, Jangkung Handoyo Mulyo ${ }^{2,3}$, Slamet Hartono ${ }^{2}$, Subejo ${ }^{2}$ \\ ${ }^{1}$ Jurusan Agribisnis, Fakultas Pertanian Universitas Tanjungpura, Pontianak, Indonesia \\ 2 Jurusan Ekonomi Pertanian, Fakultas Pertanian Universitas Gadjah Mada, Yogyakarta, \\ Indonesia \\ ${ }^{3}$ Pusat Studi Kependudukan dan Kebijakan, Universitas Gadjah Mada, Yogyakarta, Indonesia \\ Korespondensi: Jurusan Agribisnis, Fakultas Pertanian Universitas Tanjungpura, Jalan \\ Prof.Hadari Nawawi, Pontianak-Kalimantan Barat (78121), Indonesia \\ E-mail: sudrajat_jajat83@yahoo.co.id
}

\begin{abstract}
Study the role of social capital on nurturing of agribusiness sustainability is still limited. Whereas, the indepth understanding toward the role of social capital in facilitating cooperation on relationships among institutions (actors) of agribusiness is very important and strategic for planning of agricultural development. This study is aimed to describe the role of social capital in facilitating cooperation on relationships among marketing institutions of corn in Tujuh Belas sub district, Bengkayang regency. The primary data were collected by observation, focus group discussion, and indepth interview to farmers and traders. The result of this study shows that the implementation of social capital element in farming activities or agribusiness in this location, generally based on effort of resources exchange among actors. On the relationships among the farmers, social capital is implemented by exchange of household labor (strict and sort term reciprocity). Meanwhile, in relationships between farmer and village trader and also between village trader and wholesaler, the social capital is implemented by exchange of economic resources. The exchange of resources is frequent implemented by trial risk, risk sharing, and applying flexibility in any type of transaction (non strict reciprocity in the sort term). This resources's exchange is understood as effort to nurture agribusiness sustainability in the long run.
\end{abstract}

Keywords: social capital, agribusiness, sustainability, traders, bengkayang

\begin{abstract}
Abstrak
Kajian peranan social capital dalam memelihara keberlanjutan agribisnis masih relatif terbatas. Padahal pemahaman mendalam terhadap peranan social capital dalam memfasilitasi kerjasama pada hubungan antar lembaga (pelaku) agribisnis sangat penting dan strategis untuk keperluan perencanaan dan pelaksanaan pembangunan pertanian. Oleh karena itu, studi ini ditujukan untuk mendeskripsikan peranan social capital dalam memfasilitasi kerjasama pada hubungan antar lembaga pemasaran jagung di Kecamatan Tujuh Belas Kabupaten Bengkayang. Data primer penelitian dikumpulkan melalui observasi, focus group discussion (FGD), dan wawancara mendalam terhadap para petani dan pedagang. Hasil penelitian memperlihatkan bahwa implementasi unsur social capital dalam praktek usahatani dan pemasaran jagung di lokasi studi pada umumnya didasarkan pada upaya melakukan pertukaran sumber daya antar lembaga yang terlibat. Pada hubungan kerjasama antar petani, social capital diwujudkan berupa pertukaran tenaga kerja rumah tangga (pertukaran sebanding dalam jangka pendek). Sementara itu, pada hubungan kerjasama antara petani dan pedagang desa serta antara pedagang desa dan pedagang besar, social capital diimplementasikan sebagai pertukaran sumber daya ekonomi. Pertukaran sumber daya sering diwujudkan berupa penanggungan resiko, membagi resiko, dan menerapkan fleksibilitas dalam berbagai bentuk transaksi (pertukaran tidak sebanding dalam jangka pendek). Selanjutnya, pertukaran sumber daya ini dimengerti sebagai upaya memelihara keberlanjutan agribisnis dalam jangka panjang.
\end{abstract}

Kata kunci: social capital, keberlanjutan, agribisnis, pedagang, bengkayang 


\section{Pendahuluan}

Pemahaman mendalam terhadap keberhasilan dan keberlanjutan suatu cluster agribisnis memiliki posisi strategis untuk keperluan perencanaan dan pelaksanaan pembangunan pertanian. Beberapa faktor yang menjadi penentu keberlanjutan suatu aktivitas masyarakat termasuk di dalamnya keberlanjutan agribisnis menurut DFID (1999), meliputi: sumber daya alam (natural capital), sumber daya manusia (human capital), sumber daya fisik (physical capital), sumber daya financial (financial capital), dan sumber daya sosial (social capital). Kajian terhadap peran keempat sumber daya telah banyak dilakukan, sedangkan pemahaman terhadap peran social capital dinilai masih relatif sedikit. Artinya, masih sangat terbatas informasi yang dapat dijadikan rujukan mengenai peran social capital terhadap keberhasilan suatu cluster agribisnis. Padahal dalam praktek usahatani dan juga pemasaran hasil pertanian, misalnya pada kasus pemasaran jagung di Kecamatan Tujuh Belas, sangat banyak memerlukan kehadiran social capital. Komoditas pertanian (jagung) diketahui memiliki kualitas yang tidak homogen dan mudah rusak, sehingga sangat rentan menimbulkan kecurangan dalam transaksinya ketika tidak dibarengi dengan kehadiran social capital. Sementara itu, pada praktek pengelolaan usahatani (on farm) juga sangat memerlukan berbagai kerjasama baik antar petani maupun antara petani dan pedagang. Pada berbagai kerjasama tersebut, kehadiran social capital sangat diperlukan agar kemitraan yang dibangun bisa berlangsung secara berkelanjutan.

Implementasi social capital dimaksud dapat diamati dalam kerjasama pengelolaan usahatani dan pemasaran jagung di Kecamatan Tujuh Belas yang menjadi lokasi penelitian ini. Hal ini disebabkan bentuk kerjasama (kemitraan) dilakukan dengan cara yang sangat unik, yaitu dengan dicirikan oleh kuatnya kerjasama secara alamiah antara petani dan pedagang desa atau lebih dikenal sebagai pedagang pengumpul jagung (PPJ). Peran PPJ sangat menonjol dalam menjaga keberlangsungan agribisnis ini, yakni selain berperan sebagai lembaga penampung, pengolah, dan pemasaran jagung juga berperan dalam membiayai usahatani jagung, yaitu dengan memberikan pinjaman benih, pupuk organik, pupuk anorganik, obat-obatan, dan keperluan lainnya dalam usahatani jagung.

Pola agribisnis jagung seperti ini telah berlangsung cukup lama, yaitu sejak tahun 1990 ketika program transmigrasi dimulai di daerah ini. Pola agribisnis ini dapat juga dipandang sebagai model agribisnis tradisional, karena dalam menjalankan aktivitasnya tidak didasarkan pada perjanjian kontrak secara tertulis dengan beberapa persyaratan dan perjanjian yang mencakup hak dan kewajiban yang disepakati oleh kedua belah pihak. Pertanyaannya adalah bagaimana social capital kemudian bisa berperan dalam pola hubungan seperti ini? Padahal pandangan umum sering melihat posisi pedagang sangat kuat dalam struktur hubungan seperti ini dibandingkan dengan posisi petani yang lemah, sehingga menurut Syahyuti (2007) mengundang banyak pihak termasuk para pengambil kebijakan yang sering memiliki pandangan negatif (stereotype) terhadap peran pedagang hasil pertanian tersebut.

Apakah benar bahwa pedagang itu senantiasa merugikan petani yang lemah? Untuk menjawab pertanyaan ini, maka berbagai bentuk kerjasama atau peran yang dilakukan oleh masing-masing pelaku sangat penting untuk dikaji dalam perspektif social capital, guna mengungkap berbagai fakta dan fenomena yang sesungguhnya. Hal ini didasarkan pada pandangan atau keyakinan bahwa petani dan pedagang sesungguhnya merupakan dua unsur manusia yang menjadi kunci keberhasilan agribisnis. Petani diperlukan peranannya di tingkat usahatani (on farm), sedangkan pedagang juga sangat diperlukan peranannya pada kegiatan pemasaran (off-farm). Tanpa hubungan yang baik di antara keduanya melalui implementasi unsur social capital seperti trust, networks, norms, dan reciprocity, kecil kemungkinan agribisnis bisa berlangsung secara berkelanjutan (Pafchamps and Minten 1999, Syahyuti 2008). Berdasarkan pada pemikiran tersebut, maka lingkup studi ini pada dasarnya ditujukan untuk mendeskripsikan peran social capital dalam memfasilitasi kerjasama yaitu baik pada hubungan petani dengan petani, hubungan petani dengan PPJ, maupun hubungan PPJ dengan pedagang besar. Dengan perkataan lain, kajian ini ditujukan untuk mendeskripsikan peran social capital dalam memfasilitasi kerjasama pada masing-masing pelaku yang terlibat dalam menjaga keberlanjutan agribisnis jagung. 


\section{Metode Penelitian}

Penelitian ini dilakukan dengan cara melakukan survey yakni untuk menjaring berbagai fakta dan fenomena bekerjanya social capital pada hubungan antara pelaku agribisnis, yaitu baik hubungan horizontal petani dengan petani maupun hubungan vertikal petani dengan PPJ dan PPJ dengan Pedagang Besar. Pengumpulan data primer diperoleh melalui pengamatan (observation), focus group discussion (FGD), dan wawancara mendalam (indepth interview). Wawancara mendalam dilakukan terhadap petani terpilih yang dapat mewakili tiga desa penelitian, pedagang pengumpul jagung, dan pedagang besar terpilih.

Teknik wawancara mendalam dipergunakan untuk memperkaya data yang diperoleh dari hasil observasi lapangan dan FGD. Fokus permasalahan yang ditanyakan kepada petani adalah: (a) jenis pertukaran tenaga kerja dalam usahatani jagung, (b) cara melakukan pertukaran tenaga kerja, (c) siapa-siapa yang terlibat dalam pertukaran, dan (d) aturan dan sanksi dalam pertukaran. Sementara itu, fokus permasalahan yang ditanyakan kepada PPJ dan pedagang besar adalah menyangkut beberapa aspek, sebagai berikut: (a) aturan dan perjanjian yang dilakukan dalam transaksi pinjam-meminjam; menyangkut ada tidaknya bukti pinjaman dan besar pinjaman, (b) aturan dan perlindungan ketika petani mengalami kegagalan panen, (c) sanksi ketika petani melakukan penyimpangan (pelanggaran) terhadap perjanjian, (d) upaya PPJ melindungi petani ketika harga jagung jatuh (rendah), (e) cara pedagang menentukan tingkat keuntungan ketika harga tinggi, (f) berbagai jenis pelayanan yang diberikan oleh PPJ untuk memperlancar usahatani jagung, (g) cara petani dan PPJ saling mempercayai pada berbagai macam bentuk transaksi, misalnya ketika penimbangan input usahatani atau penimbangan output (jagung), (h) cara petani memberikan dukungan dan bantuan kepada PPJ, (i) aturan dan perlindungan dari pedagang besar kepada PPJ, (j) cara pedagang besar menetapkan harga jagung pada setiap harga pasar, $(\mathrm{k})$ cara pedagang besar melindungi PPJ ketika PPJ berada dalam kesulitan, dan (1) cara PPJ memberikan dukungan dan bantuan kepada pedagang besar. Waktu penelitian ini dilakukan antara bulan Juni sampai dengan Desember 2013 pada tiga desa terpilih yang menjadi sentra produksi jagung yaitu Desa Sinar Tebudak, Desa Kamuh, dan Desa Bengkilu yang berada pada wilayah administratif Kecamatan Tujuh Belas Kabupaten Bengkayang (Gambar 1).
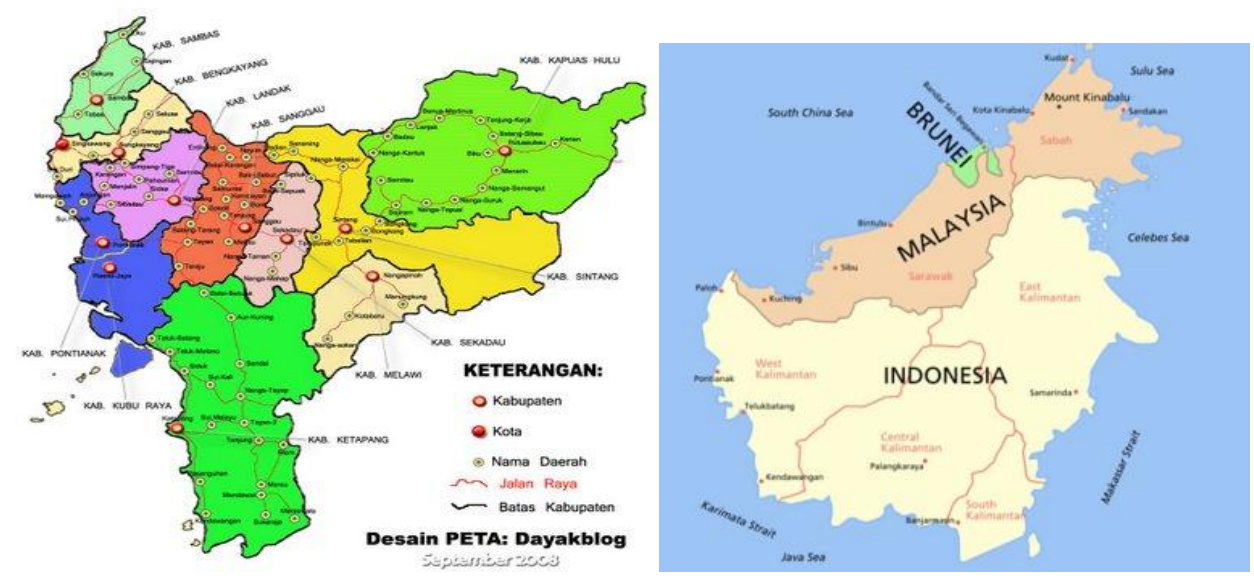

Gambar 1. Peta daerah penelitian

\section{Hasil Penelitian dan Pembahasan}

\section{Gambaran Umum}

Usahatani jagung di daerah ini berada pada suatu daerah yang dianggap paling subur di Kalimantan Barat, jenis tanahnya adalah Latosol, yaitu sejenis tanah vulkanik yang berasal dari letusan Gunung 
Niut yang ada di daerah ini. Iklim untuk usahatani jagung juga sangat mendukung, curah hujannya relatif merata sepanjang tahun dengan rata-rata curah hujan $275 \mathrm{~mm} /$ bulan dan rata-rata hari hujan sebanyak 15 hari hujan/bulan. Dipadukan dengan penyinaran matahari yang cukup banyak, maka di daerah dengan ketinggian 500 - 700 meter dari permukaan laut ini, usahatani jagung dapat dilakukan sepanjang tahun. Setidaknya dapat dilakukan tiga kali musim tanam dalam setahun.

Namun demikian, pengelolaan usahatani yang dilakukan masih bersifat sederhana (belum mencapai pola intensifikasi yang diharapkan). Hal ini dapat dicermati dari aplikasi pemupukan yang belum optimal dan penggunaan benih yang sebagian besar masih menggunakan benih lokal. Secara teknis, belum intensifnya pengelolaan usahatani jagung di daerah ini terkait dengan banyaknya curahan waktu kerja yang diperlukan dalam usahatani, sementara itu ketersediaan tenaga kerja usahatani sangat terbatas dan pada sisi lainnya mekanisasi pertanian belum berjalan sebagaimana yang diharapkan. Selain itu, dukungan pembiayaan usahatani dari lembaga formal masih belum tersedia, padahal kemampuan petani dari sisi pembiayaan sangat terbatas. Oleh karena itu, kemitraan dengan pedagang pengumpul menjadi suatu alternatif untuk menjalankan agribisnis jagung di daerah ini.

Hingga saat ini, capaian kinerja usahatani jagung ditunjukkan oleh luas tanam rata-rata per petani sebesar 1,18 hektar dan pendapatan petani per hektar sebesar 4,1 juta rupiah. Namun, secara keseluruhan usahatani jagung ini dianggap telah memberikan sumbangan yang cukup berarti bagi petani dan keluarganya dalam meningkatkan kesejahteraan dan juga dapat memberikan sumbangan bagi pengembangan ekonomi perdesaan. Hal ini dikarenakan, jagung dari daerah ini dapat diperdagangkan ke daerah lain (Kota Singkawang) melalui peran PPJ, sehingga pada gilirannya dapat meningkatkan aliran uang atau secara umum kemajuan ekonomi di wilayah perdesaan.

Berlangsungnya kelembagaan agribisnis jagung di lokasi penelitian diyakini sarat dengan penerapan nilai dan norma (social capital) yang di dalamnya berkaitan dengan bekerjanya mekanisme pertukaran sumber daya di antara para pihak yang terlibat. Untuk menganalisis peran social capital, pada penelitian ini dilihat dari hubungan antar pelaku secara berjenjang baik pada tingkat usahatani (on farm) maupun dalam kegiatan pemasaran jagung. Secara skematis hubungan antar pelaku dalam agribisnis ini dapat dilihat pada Gambar 2.

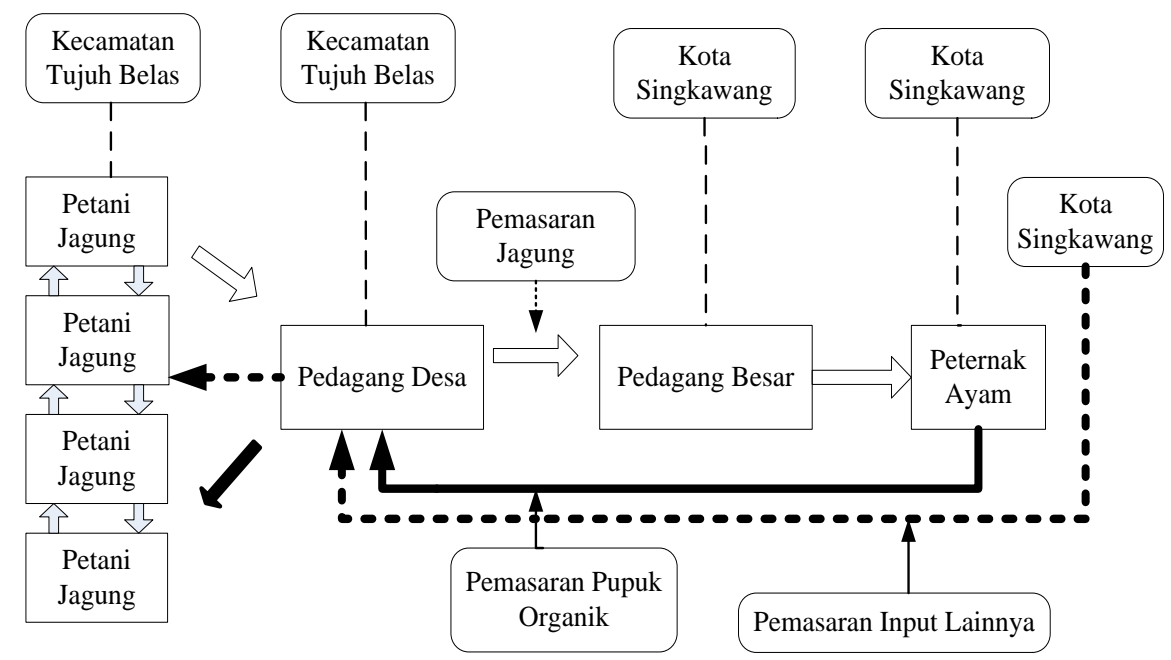

Gambar 2. Skema hubungan antar pelaku dalam pemasaran (agribisnis) jagung di Kecamatan Tujuh Belas Kabupaten Bengkayang

\section{Peran Social Capital pada hubungan kerjasama petani dengan petani}

Usahatani jagung di daerah ini boleh dikatakan telah menjadi pelopor dan pembelajaran dalam agribisnis, karena sebelumnya kegiatan usahatani yang dijalankan oleh masyarakat lokal hanya berkutat dengan kegiatan perkebunan seperti karet dan padi ladang yang tidak terlampau memerlukan pemeliharaan intensif dan perencanaan yang optimal. Pada awal perkembangan usahatani jagung di 
daerah ini tentu tidak sederhana, dukungan pemerintah juga sangat besar, seiring adanya semangat pemerintah dalam menjalankan program revolusi hijau pada waktu itu.

Peranan petani transmigran dalam mengembangkan agribisnis jagung di daerah baru ini sangat penting, awalnya budidaya jagung dilakukan secara coba-coba (trial and error) saja, yang boleh juga dikatakan sebagai watak petani (ilmu petani) dalam menemukan usaha apa yang cocok dalam suatu daerah atau wilayah. Cara coba-coba ini apabila dinilai memberikan harapan keuntungan maka akan dilanjutkan, berikutnya tentu saja akan diikuti oleh petani-petani lainnya. Dengan demikian, pada akhirnya akan terbentuk suatu kawasan agribisnis yang berkonsentrasi pada suatu komoditas tertentu, yang dalam hal ini adalah komoditas jagung. Pandangan ini dapat sedikit menjelaskan mengapa suatu daerah kemudian memiliki komoditas unggulan yang dikembangkan sedangkan daerah lainnya tidak.

Terdapat beberapa prasyarat atau kondisi, berdasarkan pengamatan lapangan, mengapa daerah ini kemudian berhasil dalam mengembangkan agribisnis jagung, antara lain: a) kondisi lahan yang cukup subur. Jenis tanah latosol dengan struktur yang gembur dan tekstur sedang sangat cocok untuk usahatani jagung; b) keterkaitan agribisnis dengan wilayah lain (daerah perkotaan), sehingga tersedia pasar komoditas jagung. Pada kaitan ini jagung dari daerah ini berperan sebagai barang input (intermediate good) bagi usaha peternakan ayam ras di Kota Singkawang (Gambar 2); c) sumber daya manusia petani dan budaya yang dimilikinya sangat mendukung berjalannya agribisnis jagung berlangsung optimal. Petani transmigran yang berasal dari berbagai daerah di Pulau Jawa, telah memiliki budaya dan pengalaman bertani yang cukup baik, sehingga pemerintah daerah pada waktu itu tinggal sedikit mengarahkan dan membinanya.

Salah satu pendukung berlangsungnya agribisnis jagung di daerah ini, adalah kebiasaan masyarakat Jawa bergotong-royong dalam berbagai hal termasuk dalam menjalankan usahatani. Kegiatan bergotong-royong ini, secara umum dapat dinilai sebagai wujud social capital di Indonesia sebagaimana dinyatakan oleh Subejo (2004). Wujud social capital dalam agribisnis jagung di daerah ini dapat dilihat dalam hubungan kerjasama petani dengan petani yaitu berupa pertukaran tenaga kerja yang dinamakan "Lalian" (bahasa Jawa). Dengan perkataan lain, pekerjaan pada usahatani jagung, selain dikerjakan oleh tenaga keluarga dan tenaga upahan, dikerjakan pula dengan cara gotongroyong. Pertukaran tenaga kerja dalam aktivitas pertanian ini, memiliki beberapa keuntungan yaitu selain berperan menghemat pengeluaran usahatani juga sebagai respon mengatasi langkanya tenaga kerja pertanian, selain itu secara sosial juga berperan sebagai jembatan untuk mempererat hubungan di antara para petani (social cohesiveness). Menurut Subejo (2009) pertukaran tenaga kerja ini tergolong dalam pertukaran setara dalam jangka pendek (strict and sort term reciprocity). Dengan demikian dapat dikemukakan bahwa peranan social capital dalam hal ini adalah berupa pengurangan biaya usahatani dan dapat terpenuhinya kebutuhan tenaga kerja usahatani.

Tenaga kerja pertanian dapat dipandang langka di daerah ini, mengingat jumlah penduduk yang relatif sedikit dibandingkan dengan luas wilayahnya, man-land ratio baru mencapai 0,52 yang berarti bahwa setiap orang di lokasi penelitian masih diimbangi oleh sekitar 0,52 hektar lahan (BPS 2013). Di samping itu rata-rata kepemilikan lahan juga cukup luas dan hampir tidak ada petani yang tidak memiliki lahan. Dengan demikian, masing-masing rumah tangga petani sibuk dengan aktivitas usahataninya masing-masing. Oleh karena itu, pertukaran tenaga kerja merupakan alternatif yang rasional serta cara hidup yang cocok bagi petani di daerah perdesaan seperti ini. Beberapa jenis pekerjaan dalam usahatani jagung yang sering dilakukan pertukaran tenaga kerja adalah pada pekerjaan pembukaan lahan, pengolahan lahan, dan penanaman. Pada pekerjaan penanaman apabila lahannya cukup luas diperlukan tenaga kerja cukup banyak, karena pada saat penanaman terdapat pekerjaan memasukan benih jagung pada lubang tanam dan pekerjaan pemupukan yaitu memberikan pupuk organik dan anorganik. Melalui cara gotong-royong ini maka pekerjaan dapat dilakukan pada waktu yang relatif lebih singkat. Namun demikian, selalu terdapat fleksibilitas dalam melakukan pertukaran tenaga kerja tersebut. Sebagai contoh, untuk peserta Lalian yang tidak sempat membalas pada pekerjaan penanaman maka bisa juga membalas pada pekerjaan lainnya misalnya pada pekerjaan penyiangan atau pemanenan. 
Pada sisi lainnya, pertukaran sumber daya juga tampak dalam norma saling memberi hasil ikutan (by product) tanaman jagung untuk pakan ternak sapi. Sementara itu, terkait dengan organisasi lokal di tingkat komunitas, bekerjanya social capital juga sering terlihat pada aktivitas kelompok tani. Petani yang tergabung pada kelompok tani di lokasi penelitian pada umumnya aktif membayar iuran kelompok untuk berbagai kegiatan yang direncanakan. Keaktifan pada kelompok tani ini selain membawa berbagai aliran informasi yang dapat mendorong keberhasilan usahatani juga menjadi wahana yang efektif untuk mendapatkan akses terhadap berbagai bantuan dari pemerintah. Kelompok tani pada dasarnya merupakan kelembagaan yang dibentuk dari luar untuk kepentingan pembangunan pertanian oleh pemerintah (Syahyuti 2003).

Pertukaran tenaga kerja di antara keluarga petani ini selain dilakukan antar tenaga kerja laki-laki juga dilakukan antar tenaga kerja perempuan. Hal ini sangat tergantung pada jenis pekerjaan dalam usahataninya. Tenaga kerja laki-laki umumnya digunakan untuk pekerjaan yang memerlukan kekuatan yang lebih besar, meskipun waktunya relatif lebih singkat, sedangkan tenaga kerja perempuan umumnya digunakan untuk pekerjaan yang memerlukan ketelitian dan ketekunan. Data tentang pembagian pekerjaan dalam usahatani jagung di daerah penelitian dapat dilihat pada Tabel 1. Setiap kelompok dalam melakukan pertukaran tenaga kerja (Lalian) di daerah ini pada umumnya terdiri dari lima sampai tujuh orang, besarnya kelompok tersebut sangat tergantung pada rasa saling percaya, keeratan hubungan, dan jumlah rumah tangga terdekat yang mengusahakan tanaman yang sama yaitu jagung.

Tabel 1.

Jenis pekerjaan dan pelaku dalam usahatani jagung

\begin{tabular}{lccccl}
\hline Jenis Pekerjaan & Laki-laki & \multicolumn{2}{c}{ Perempuan } & \multicolumn{2}{c}{ Pola Tenaga Kerja } \\
\cline { 2 - 5 } & Dewasa & $\begin{array}{c}\text { Anak- } \\
\text { anak }\end{array}$ & Dewasa & $\begin{array}{c}\text { Anak- } \\
\text { anak }\end{array}$ & \\
\hline Pembukaan lahan & $\mathrm{S}$ & $\mathrm{T}$ & $\mathrm{K}$ & $\mathrm{T}$ & Keluarga, Upahan, Lalian \\
Pengolahan lahan & $\mathrm{S}$ & $\mathrm{T}$ & $\mathrm{K}$ & $\mathrm{T}$ & Keluarga, Upahan, Lalian \\
Penanaman & $\mathrm{S}$ & $\mathrm{K}$ & $\mathrm{S}$ & $\mathrm{K}$ & Keluarga, Upahan, Lalian \\
Pemupukan & $\mathrm{S}$ & $\mathrm{K}$ & $\mathrm{S}$ & $\mathrm{K}$ & Keluarga, Upahan \\
Penyiangan & $\mathrm{S}$ & $\mathrm{T}$ & $\mathrm{K}$ & $\mathrm{T}$ & Keluarga, Upahan \\
Pemanenan & $\mathrm{S}$ & $\mathrm{K}$ & $\mathrm{S}$ & $\mathrm{K}$ & Keluarga, Upahan, Lalian \\
\hline
\end{tabular}

Sumber: Data primer (pengamatan lapangan) 2013

Keterangan: $\mathrm{S}=$ sering, $\mathrm{K}=$ kadang-kadang, $\mathrm{T}=$ tidak pernah

\section{Peran social capital pada hubungan kerjasama petani dengan PPJ}

Keberlanjutan agribisnis jagung di daerah ini tidak terlepas dari peran besar PPJ yang banyak didasarkan pada penerapan social capital. Pola kemitraan petani dengan PPJ ini, sepertinya telah menjadi ciri khusus dan memiliki keunikan tersendiri. Keunikannya adalah PPJ mau membiayai usahatani jagung yang dijalankan oleh para petani di sekitarnya, karena biasanya pedagang pengumpul itu hanya bersedia menampung hasil usahatani saja, kalaupun bersedia memberi pinjaman biasanya tidak terlampau besar hanya sekedar untuk memberi ikatan moral kepada para petani. Sebagai contoh, di lokasi penelitian terdapat pula pedagang pengumpul sayuran, tetapi tidak memberi pinjaman sarana produksi seperti pada kasus PPJ.

Secara konseptual model kemitraan petani dengan PPJ ini, dapat disejajarkan dengan pola contract farming, namun dalam kasus ini karena pada umumnya dijalankan secara informal, maka bisa pula dinamakan sebagai "informal contract farming". Adapun pengertian usahatani kontrak (contract farming) sendiri menurut Colin Kirk dalam Gunawan et al. (1995) adalah sebagai berikut: 
Contract farming adalah suatu cara mengatur produksi pertanian, dengan cara para petani kecil (outgrower) dikontrak oleh suatu badan sentral untuk memasok hasil pertanian sesuai dengan syarat-syarat yang telah ditentukan dalam sebuah kontrak atau perjanjian.

Pada kemitraan ini, PPJ dikondisikan bertindak sebagai badan yang berperan menyiapkan dan memberi pinjaman sarana produksi usahatani, seperti benih, pupuk organik, pupuk anorganik (Urea, SP-36, Phonska), obat-obatan (herbisida, insektisida). Selain itu, juga melakukan pengolahan hasil (pasca panen) dan menampung (memasarkan) seluruh produksi jagung yang dihasilkan oleh para petani. Adapun pembayaran pinjaman dari petani kepada PPJ dilakukan segera setelah panen jagung, namun demikian selalu terdapat fleksibilitas dalam pembayaran pinjaman ini, misalnya ketika petani mengalami kegagalan panen karena serangan hama maka pembayaran pinjaman dapat ditunda pada musim berikutnya. Artinya sepanjang kejadian atau peristiwa itu rasional maka pembayaran pinjaman dapat saja ditunda tergantung kesepakatan dan toleransi yang diberikan oleh PPJ. Adanya fleksibilitas seperti ini menunjukkan bahwa model kemitraan ini banyak didasarkan pada penerapan social capital. Kenyataan ini memberi gambaran bahwa social capital berperan penting untuk memfasilitasi terpenuhinya kebutuhan petani dalam penyediaan input usahatani jagung.

Selanjutnya, kemitraan antara petani dan PPJ dari mulai panen hingga pemasaran dapat diuraikan sebagai berikut: Pertama, kemitraan pada kegiatan pemanenan. Kebun jagung yang akan di panen, sebelumnya harus dilakukan pengeringan buah jagung dalam pohon yang lamanya sekitar dua minggu. Jagung yang telah dipetik dari pohon, dikupas kelobotnya dan kemudian dimasukan ke dalam karung. Selanjutnya jagung tongkolan yang telah dimasukan dalam karung ini dikumpulkan di lahan atau di tepi jalan terdekat, tergantung kondisi sampai seberapa jauh truk pengangkut milik PPJ dapat mencapai lokasi lahan milik para petani.

Jagung milik petani ini kemudian akan dirontokkan dari tongkolnya dengan mesin pemipil jagung (threser). Pekerjaan ini dilakukan di tempat (gudang) milik PPJ. Pada waktu sebelumnya, menurut keterangan para pedagang, pekerjaan memipil dengan threser ini dilakukan di rumah masing-masing petani, pedagang yang datang ke rumah petani dengan seperangkat karyawannya dan dibantu oleh petani dan anggota keluarga lainnya yaitu istri petani atau anaknya. Oleh karena itu, hingga saat ini pekerjaan pemipilan ini, menjadi tanggung jawab petani dengan dibantu oleh PPJ, namun polanya agak berbeda, kalau pada masa sebelumnya petani pemilik dan anggota keluarga lainnya yang ikut bekerja memipil, saat ini semuanya diserahkan kepada para pekerja di tempat PPJ dengan pola upahan. Perubahan pola ini terjadi terkait dengan cara pengeringannya, kalau pada masa sebelumnya jagung yang telah dipipil tersebut dikeringkan dengan cara dijemur pada terik matahari di pekarangan rumah petani, saat ini menggunakan mesin pengering (dryer) yang dimiliki pedagang pengumpul.

Pada pekerjaan pemipilan di tempat PPJ ini, dua tenaga kerja merupakan tanggungan petani dalam hal upahnya, yaitu sebesar Rp 1.500,-/karung jagung tongkolan. Demikian pula untuk upah muat bongkar dalam pengangkutan jagung dari lahan milik petani ke tempat PPJ dibayar sebesar Rp 1.500,-/karung. Dengan demikian, apabila jagung petani itu sebanyak 100 karung, maka upah muat bongkar pengangkutan dan memipil jagung menjadi sekitar Rp 300.000,-. Adapun biaya angkutan (kendaraan) termasuk sopir adalah menjadi tanggungan PPJ, karena sopir merupakan karyawan PPJ.

Kedua, kemitraan pada kegiatan pengeringan dan penimbangan. Setelah dipipil, jagung kemudian dikeringkan dengan mesin pengering dan dikemas dalam karung. Biaya pengeringan ini menjadi tanggungan PPJ, sedangkan biaya karungnya menjadi tanggungan petani. Tahap ini selanjutnya diakhiri oleh kegiatan penimbangan dan pemasaran jagung. Pada pekerjaan penimbangan jagung yang telah dikeringkan ini, seluruhnya dilakukan oleh karyawan PPJ, jarang sekali atau hampir tidak pernah disaksikan oleh para petani yang bersangkutan. Sekali lagi, mekanisme saling percaya (mutual trust) telah menjadi dasar berlangsungnya kerjasama antara petani dengan PPJ. Petani percaya terhadap kejujuran PPJ beserta karyawannya, sehingga semuanya dapat berjalan efektif dan efisien, setidaknya dalam hal ini telah terjadi efisiensi dalam menghemat waktu yang dimiliki petani di daerah ini yang sudah cukup sibuk dengan berbagai kegiatan pertanian seperti; noreh karet, memelihara ternak, atau pekerjaan lainnya. Namun demikian, menurut para PPJ, petani juga dapat memperkirakan jagung 
kering pipilan yang dihasilkannya, yaitu dengan berpatokan pada banyaknya jagung yang dikarungkan ketika diangkut dari lahan. Untuk setiap ton jagung kering pipilan, yaitu pada isian karung dengan baik biasanya berasal dari sekitar 42-44 karung jagung tongkolan yang belum dipipil. Sampai pada titik ini dapat disimpulkan pula bahwa peranan social capital dalam kegiatan pasca panen jagung adalah terciptanya efisiensi dan efektivitas kerja sehingga dapat mengurangi biaya pengawasan atau biaya monitoring.

Pada mekanisme kemitraan tersebut, peranan PPJ dalam menjaga keberlanjutan agribisnis jagung setidaknya dapat diidentifikasi dalam tiga aspek yaitu: Pertama, aspek pengangkutan (transportasi). Untuk pengangkutan material seperti pupuk (organik dan anorganik) atau hasil panen jagung ke dan dari lahan garapan petani, tanpa bantuan kendaraan yang dimiliki pedagang, pada dasarnya relatif sulit untuk dilakukan oleh petani secara individu karena petani pada umumnya tidak memiliki kendaraan seperti pickups atau truck, apalagi ketika lahan usahatani cukup jauh dari permukiman atau jalan desa dengan kondisi jalan yang kurang baik.

Kedua, aspek perlindungan kualitas. Ada kalanya, produksi jagung petani mengalami penurunan kualitas yang sulit untuk dihindari, biasanya terjadi ketika panen jagung berada pada kondisi curah hujan yang cukup tinggi, yaitu antara bulan Oktober hingga Januari. Pada saat ini, jagung yang dihasilkan petani, sering mengalami sedikit penurunan kualitas yaitu beberapa biji jagung terlihat agak kusam. Warna biji jagung yang agak kusam ini sangat sulit dilakukan pemisahan karena jumlahnya yang cukup banyak. Melalui kerjasama kemitraan dengan PPJ dan juga pedagang besar, jagung petani ini tetap bisa dipasarkan, yang dalam suatu kesempatan kadang-kadang ditolak oleh para peternak di Kota Singkawang. Artinya para peternak di Kota Singkawang sering menetapkan persyaratan mutu yang lebih ketat (bukan berarti jagung ini tidak bisa dimanfaatkan untuk pakan ternak), terutama ketika stok jagung yang dimiliki peternak dirasakan masih cukup banyak misalnya ketika lebih mudah memperoleh jagung dari daerah lain.

Ketiga, aspek perlindungan harga. Problematika yang sering mengganggu dalam usahatani jagung di daerah ini, menurut keterangan beberapa petani dan pedagang adalah sering terjadinya gejolak harga jagung di pasaran. Penyebab penurunan harga adalah sering masuknya jagung dari daerah lain ke Kota Singkawang baik dari Semarang maupun kadang-kadang dari Malaysia. Masuknya jagung ke Kota Singkawang adalah sebagai upaya para peternak ayam di kota tersebut untuk menjamin stabilnya pasokan jagung. Para peternak ayam di Kota Singkawang yang dikelola oleh etnis Tionghoa, dari sisi bisnis memang dapat dikategorikan sudah cukup kuat, bahkan salah satunya dilaporkan memiliki kapal motor yang dapat mengangkut jagung dan berbagai barang dagangan lainnya dari Kota Semarang atau kota lainnya di Pulau Jawa.

Ketika harga jagung cukup tinggi tentu tidak banyak menimbulkan persoalan, misalnya kalau harga di tingkat peternak di Kota Singkawang Rp3.900,-/kg, maka harga beli ke petani sekitar Rp3.000,-/kg. Pedagang besar memperoleh selisih harga Rp400,-/kg, sedangkan PPJ memperoleh selisih harga sekitar Rp500, $/ \mathrm{kg}$, selisih harga di tingkat PPJ ini digunakan untuk menutupi biaya pengangkutan jagung dari lahan petani, pengeringan dengan menggunakan dryer, upah karyawan, biaya pengangkutan ke Kota Singkawang, dan keuntungan yang ingin diperoleh PPJ. Sebaliknya, ketika harga jagung sedang jatuh, maka akan banyak menimbulkan permasalahan bagi petani yang posisinya paling lemah. Namun dalam kasus ini PPJ tetap melindungi petani, yaitu dengan cara mengambil selisih harga sedikit saja, kadang-kadang hanya diperuntukkan untuk menutupi biaya pengangkutan, misalnya hanya mengambil selisih harga Rp10,-/kg. Demikianlah peran atau upaya yang dijalankan oleh PPJ dalam melindungi petani, terutama dalam menjaga semangat petani menjalankan usahatani jagung. Sebab, harapan keuntungan PPJ sesungguhnya juga tidak hanya berasal dari usahatani jagung, tetapi juga bersumber dari penjualan pupuk (organik/anorganik) dan input usahatani lainnya (Gambar 2). Jadi, dalam hal ini, aspek rasionalitasnya juga tetap ada.

PPJ selain berperan dalam memberikan pinjaman berupa barang (sarana produksi usahatani), dalam banyak kesempatan juga memberikan pinjaman uang tunai. Pinjaman berupa uang tunai ini hanya diberikan kepada petani yang sudah sangat dikenalnya melalui hubungan yang sudah berlangsung 
lama. Pinjaman berupa sarana produksi usahatani dan pinjaman uang pada umumnya dicatat secara sederhana di pembukuan milik PPJ. Namun dalam beberapa kasus yang boleh dianggap terlampau ekstrim, kadang-kadang pencatatan dipercayakan kepada petani yang meminjam. Hal ini dilakukan jika sudah merasa sangat percaya dengan petani yang bersangkutan.

Berkaitan dengan kasus ini, sangat bermanfaat untuk menjelaskan bahwa hubungan kemitraan antara petani dengan PPJ banyak didasarkan pada nilai (norma) yang berlaku di tingkat lokal dengan mendasarkan pada rasa saling percaya (mutual trust) dan saling pengertian di antara dua belah pihak. Sanksi yang dapat diberikan kepada yang menyalahi kontrak informal ini hanyalah sebuah sanksi sosial yang berlaku dalam masyarakat, misalnya tidak diberi pinjaman lagi dalam waktu/periode berikutnya, dll. Sistem usahatani kontrak seperti ini, pada dasarnya pula merupakan suatu cara membagi resiko dan keuntungan di antara pelaku yang terlibat sebagaimana dinyatakan oleh Gunawan et al. (1995), bahwa masing-masing pelaku dalam hubungan kemitraan akan bertindak dan berperilaku sedemikian rupa, dengan alasan utama memperkecil resiko dan atau mengoptimalkan keuntungannya.

Aspek paling penting dari kasus kemitraan sebagaimana diuraikan di atas adalah bahwa PPJ pada dasarnya memainkan dua peranan penting, yaitu baik dari segi kehidupan ekonomi maupun sisi kehidupan sosial. PPJ yang mampu memerankan dua aspek kehidupan ini yang akan berhasil dalam menjalankan usaha. Artinya, dalam hal ini PPJ harus mampu menjaga keseimbangan antara aspek kehidupan ekonomi dan sosialnya. Ketika PPJ terlalu kuat menonjolkan segi kehidupan ekonominya (komersialisasi), secara perlahan akan ditinggalkan oleh para petani, sedangkan sebaliknya apabila terlalu menonjolkan sisi kehidupan sosialnya, maka secara ekonomi PPJ akan mengalami masalah dalam usaha. Banyak bukti PPJ di lokasi penelitian yang kemudian ditinggalkan oleh para petani mitranya karena kurang terakomodasinya norma timbal balik di antara kedua belah pihak.

Secara sosiologis, pedagang desa sebagaimana dinyatakan oleh Damsar (2009) sering menghadapi dilema, yaitu pada satu sisi ketika berhadapan dengan petani di sekitarnya pedagang harus mengembangkan aspek kehidupan sosial bergandengan dengan orientasi ekonominya, sedangkan pada sisi lainnya ketika berhadapan dengan dunia luar pedagang harus bertemu dengan kehidupan ekonomi yang sering dicirikan oleh fluktuasi harga yang liar. Dengan perkataan lain, apabila aktivitas PPJ ini terlalu berorientasi mengikuti keinginan dari para petani serta mengabaikan rasionalitas untung rugi (cost and benefit calculation), maka akan terancam bangkrut. Kemampuan menghadapi dilema ini, dapat menjadi cara seleksi bagi PPJ, sehingga ada yang mampu bertahan dan ada pula yang harus meninggalkan bisnis ini.

Kenyataan di atas, memberi pemahaman bahwa untuk menjadi seorang PPJ yang berhasil ternyata tidak mudah dan mungkin dipengaruhi pula oleh latar belakang yang melingkupi sisi kehidupan PPJ sebelumnya. Berdasarkan fakta di lapangan setidaknya terdapat tiga latar belakang pekerjaan sebelum menggeluti pekerjaan PPJ ini, yaitu: 1) memulai pekerjaan sebagai petani jagung yang berhasil dibandingkan petani di sekitarnya; 2) pernah membantu PPJ lain dalam kegiatan bisnis ini; 3) meneruskan pekerjaan orang tua; 4) sebagai pedagang kebutuhan pokok masyarakat. Para PPJ yang mengawali pekerjaannya sebagai petani dan pernah bekerja pada PPJ lainnya cenderung lebih tahu mengenai aktivitas yang mesti dilakukan dalam mengorganisir bisnis ini baik dari sisi ekonomi (aspek rasionalitas) maupun dari sisi sosial (aspek moral). Dengan demikian, melalui latar belakang tersebut akan lebih mudah untuk memasuki kegiatan bisnis ini daripada yang memiliki latar belakang pekerjaan lainnya. Sampai pada pembahasan ini, secara ringkas peran petani dan PPJ dalam menjaga keberlanjutan agribisnis jagung dapat dilihat pada Tabel 2. 
Tabel 2.

Peran petani dan PPJ dalam menjaga keberlanjutan agribisnis jagung.

\begin{tabular}{|c|c|c|c|}
\hline Nama Kegiatan & $\begin{array}{c}\text { Cara Kerja dan Alat/Bahan } \\
\text { Digunakan }\end{array}$ & Pelaku & Keterangan \\
\hline \multirow[t]{4}{*}{ Pemanenan } & $\begin{array}{l}\text { Pembakaran pohon dan } \\
\text { jagung tongkolan di lahan }\end{array}$ & $\begin{array}{l}\text { Petani/Tenaga } \\
\text { Upahan/Lalian }\end{array}$ & - \\
\hline & $\begin{array}{l}\text { Mengupas kelobot jagung } \\
\text { yang masih tersisa }\end{array}$ & $\begin{array}{l}\text { Petani/Tenaga } \\
\text { Upahan/Lalian }\end{array}$ & - \\
\hline & $\begin{array}{l}\text { Memasukan jagung } \\
\text { tongkolan ke dalam karung }\end{array}$ & $\begin{array}{l}\text { Petani/Tenaga } \\
\text { Upahan/Lalian }\end{array}$ & - \\
\hline & $\begin{array}{l}\text { Menumpuk jagung } \\
\text { tongkolan dalam karung di } \\
\text { lokasi terdekat ke jalan }\end{array}$ & $\begin{array}{l}\text { Petani/Tenaga } \\
\text { Upahan/Lalian }\end{array}$ & - \\
\hline $\begin{array}{l}\text { Pengangkutan } \\
\text { dan bongkar } \\
\text { muat }\end{array}$ & $\begin{array}{l}\text { Muat bongkar jagung } \\
\text { tongkolan di lahan dan } \\
\text { gudang PPJ }\end{array}$ & $\begin{array}{l}\text { Karyawan } \\
\text { (Tenaga Upahan } \\
\text { di PPJ) }\end{array}$ & $\begin{array}{l}\text { Upah tanggungan petani yaitu } \\
\text { Rp } 1500,-/ \text { karung jagung } \\
\text { tongkolan, sedangkan biaya } \\
\text { operasional kendaraan } \\
\text { tanggungan PPJ }\end{array}$ \\
\hline $\begin{array}{l}\text { Perontokan } \\
\text { jagung }\end{array}$ & Menggunakan threser & Karyawan & $\begin{array}{l}\text { Upah tanggungan petani yaitu } \\
\mathrm{Rp} 1500,-/ \text { karung jagung } \\
\text { tongkolan. Sementara itu, biaya } \\
\text { operasional thresher menjadi } \\
\text { tanggungan PPJ }\end{array}$ \\
\hline Pengeringan & Menggunakan dryer & Karyawan & Upah tanggungan PPJ \\
\hline Penimbangan & $\begin{array}{l}\text { Menggunakan timbangan } \\
\text { duduk milik PPJ }\end{array}$ & Karyawan & $\begin{array}{l}\text { Dipercayakan sepenuhnya oleh } \\
\text { petani kepada PPJ dan atau } \\
\text { Karyawan PPJ }\end{array}$ \\
\hline Pemasaran & Menggunakan truk milik PPJ & PPJ, Karyawan & Biaya tanggungan PPJ \\
\hline
\end{tabular}

Peran social capital pada hubungan kerjasama PPJ dengan pedagang besar

Keberlanjutan agribisnis jagung di daerah ini, selain secara langsung berhubungan dengan peran PPJ, secara tidak langsung juga terkait dengan peran pedagang besar (wholesaler) dalam jaringan pemasaran jagung. Setiap PPJ di Kecamatan Tujuh Belas biasanya telah memiliki mitra pedagang besar tertentu yang sudah tetap di Kota Singkawang, demikian pula setiap pedagang besar juga telah memiliki beberapa mitra peternak tertentu di sekitar Kota Singkawang. Belum diketahui secara pasti apakah ada pedagang besar yang juga memiliki peternakan ayam atau hanya melulu berperan sebagai pedagang jagung. Namun, menurut keterangan para PPJ, kerap kali mengantarkan jagung ke pedagang besar selalu disuruh membongkar jagung yang dimuat dalam truk di lokasi peternakan ayam yang menjadi mitra pedagang besar. Truk pengangkut jagung tersebut pada saat pulang diisi dengan pupuk organik dari kotoran ayam, dan kemudian PPJ atau sopir truk yang menjadi utusan PPJ mampir di kantor pedagang besar untuk menerima pembayaran jagung. Pada saat pembayaran jagung ini langsung dikurangi dengan nilai pupuk organik yang dibawa PPJ.

Sebenarnya para PPJ dapat saja menjual jagungnya secara langsung kepada peternak, namun menurut keterangan para PPJ pembayarannya sering tidak lancar, misalnya jika pengiriman pertama dan kedua dibayar tunai maka pengiriman ketiga akan ditunda pembayarannya dengan alasan masih menunggu perputaran uang dari hasil penjualan telur ayam. Sebaliknya, apabila penjualan jagung melewati pedagang besar selalu dibayar tunai oleh pedagang besar. Terdapat selisih antara harga jagung di peternakan ayam dengan harga jagung di pedagang besar, selisih harga (margin) ini merupakan 
keuntungan yang ingin diperoleh para pedagang besar. Pertanyaannya adalah mengapa PPJ tidak menjual langsung ke peternak? terdapat alasan yang dari sisi social capital sangat penting, yaitu terkait dengan menjaga keberlanjutan usaha (agribisnis) dengan memanfaatkan jaringan (network). Melalui kemitraan dengan pedagang besar, sebagaimana telah dikemukakan di atas, jagung selalu bisa dipasarkan meskipun sedikit mengalami penurunan kualitas yang biasanya terjadi ketika panen jagung berlangsung pada kondisi curah hujan yang cukup tinggi, yaitu antara bulan Oktober hingga Januari. Berdasarkan kenyataan ini, maka dapat disimpulkan bahwa peranan social capital yang dimiliki oleh PPJ dan pedagang besar adalah menjamin terpeliharanya keberlanjutan agribisnis jagung.

Memperhatikan rangkaian agribisnis dari mulai petani, PPJ, pedagang besar, dan peternak, masingmasing pelaku terlihat memiliki peranan penting dalam menjaga keberlanjutan agribisnis yaitu melalui mekanisme saling memberi keuntungan dan saling menyebarkan resiko (profit and risk sharing). Mekanisme tersebut dapat dirinci sebagai berikut: (a) petani mendapatkan keuntungan dari penjualan jagung dan memperoleh manfaat kelancaran aktivitas usahatani melalui pinjaman sarana produksi yang diberikan oleh PPJ; (b) PPJ mendapatkan keuntungan dari penjualan jagung dan sarana produksi kepada petani sekaligus menanggung resiko dari kemungkinan adanya penyelewengan terhadap komitmen yang dilakukan oleh petani; (c) pedagang besar memperoleh keuntungan dari selisih harga jagung dan harga pupuk organik di tingkat peternak dengan harga di tingkat PPJ. Sebaliknya pedagang besar juga menanggung resiko (dalam dimensi waktu) dari kemungkinan penundaan pembayaran yang dilakukan oleh peternak; (d) peternak memperoleh manfaat dari terpenuhinya kebutuhan jagung sebagai pakan ternak dan mendapatkan keuntungan dari kelancaran penjualan pupuk organik; (e) PPJ dan pedagang besar berupaya meminimalkan resiko yang dihadapi petani pada saat terjadi penurunan kualitas jagung dengan mengupayakan pembelian jagung oleh peternak.

Beberapa fakta di atas, memberikan pemahaman bahwa pedagang besar dengan kemampuan keuangannya yang cukup besar, terlihat memiliki peran penting dalam menjaga kelancaran pembayaran kepada PPJ dan tentunya juga kepada para petani yang ada di desa. Pada rantai pemasaran jagung ini, peran utama pedagang besar adalah dalam menanggung resiko dari kemungkinan adanya penundaan pembayaran oleh peternak. Demikianlah sebuah jaringan agribisnis yang diperankan oleh para pelaku dikembangkan bukan hanya untuk tujuan sesaat (jangka pendek) melainkan dikelola untuk tujuan keberlanjutan dalam jangka panjang. Pada kasus ini mekanisme berlangganan (networking) terbukti menjadi syarat terjadinya keberlanjutan usaha, dan unsur social capital berupa rasa saling percaya (mutual trust) telah menjadi unsur utama dalam menjaga keberlanjutan agribisnis jagung di lokasi tersebut. Hal ini selaras dengan pendapat Fukuyama (1995) bahwa unsur inti dari social capital adalah berupa kepercayaan (trust). Sampai pada titik ini, maka dapat dirumuskan beberapa bukti peran social capital dalam memfasilitasi kerjasama antar pelaku agribisnis jagung di lokasi studi sebagaimana disajikan pada Tabel 3. 
Tabel 3.

Bukti peran social capital dalam agribisnis jagung di kecamatan tujuh belas Kabupaten Bengkayang.

\begin{tabular}{lllll}
\hline $\begin{array}{l}\text { Level } \\
\text { Kegiatan }\end{array}$ & Kegiatan/Kejadian & $\begin{array}{l}\text { Bentuk } \\
\text { Social Capital }\end{array}$ & $\begin{array}{l}\text { Unsur } \\
\text { Social Capital }\end{array}$ & $\begin{array}{l}\text { Peran } \\
\text { Capital }\end{array}$ \\
\hline Usahatani & $\begin{array}{l}\text { Pertukaran tenaga kerja } \\
\text { rumah tangga (Lalian). }\end{array}$ & $\begin{array}{l}\text { Pertukaran tenaga } \\
\text { kerja }\end{array}$ & $\begin{array}{l}\text { Norms } \\
\text { of reciprocity }\end{array}$ & $\begin{array}{l}\text { Penurunan biaya } \\
\text { usahatani }\end{array}$ \\
& $\begin{array}{l}\text { Pertukaran hasil ikutan } \\
\text { (by product) tanaman } \\
\text { jagung sebagai pakan } \\
\text { ternak sapi }\end{array}$ & Pertukaran sumber & $\begin{array}{l}\text { Norms } \\
\text { of reciprocity }\end{array}$ & $\begin{array}{l}\text { Terpenuhi } \\
\text { kebutuhan } \\
\text { pakan ternak }\end{array}$ \\
& $\begin{array}{l}\text { Panjaman input produksi } \\
\text { usahatani jagung }\end{array}$ & $\begin{array}{l}\text { Pertukaran sumber } \\
\text { daya }\end{array}$ & $\begin{array}{l}\text { Norms } \\
\text { of reciprocity, } \\
\text { mutual trust }\end{array}$ & $\begin{array}{l}\text { Terpenuhi } \\
\text { kebutuhan } \\
\text { sarana produksi } \\
\text { usaha } \\
\text { jagung }\end{array}$ \\
& & & & tani
\end{tabular}

\begin{tabular}{|c|c|c|c|c|}
\hline $\begin{array}{l}\text { Pasca } \\
\text { Panen }\end{array}$ & $\begin{array}{l}\text { Penimbangan hasil panen } \\
\text { jagung dalam bentuk } \\
\text { jagung pipilan }\end{array}$ & $\begin{array}{l}\text { Penimbangan hasil } \\
\text { panen jagung } \\
\text { dipercayakan } \\
\text { sepenuhnya } \\
\text { kepada PPJ }\end{array}$ & Mutual trust & $\begin{array}{l}\text { Peningkatan } \\
\text { efektivitas dan } \\
\text { efisiensi kerja, } \\
\text { serta penurunan } \\
\text { biaya } \\
\text { monitoring }\end{array}$ \\
\hline \multirow[t]{3}{*}{ Pemasaran } & Kejatuhan harga jagung & $\begin{array}{l}\text { PPJ melakukan } \\
\text { penanggungan } \\
\text { resiko dengan } \\
\text { tanpa mengambil } \\
\text { untung }\end{array}$ & Norms & $\begin{array}{l}\text { Terpelihara } \\
\text { Keberlanjutan } \\
\text { agribisnis }\end{array}$ \\
\hline & $\begin{array}{l}\text { Penurunan kualitas jagung } \\
\text { ketika curah hujan sangat } \\
\text { tinggi (Bulan Oktober- } \\
\text { Januari) }\end{array}$ & $\begin{array}{l}\text { PPJ dan pedagang } \\
\text { besar melakukan } \\
\text { penanggungan } \\
\text { resiko dengan } \\
\text { mengupayakan } \\
\text { membeli jagung } \\
\text { petani }\end{array}$ & Norms & $\begin{array}{l}\text { Terpelihara } \\
\text { Keberlanjutan } \\
\text { agribisnis }\end{array}$ \\
\hline & $\begin{array}{lr}\text { Penjualan } & \text { jagung } \\
\text { melewati pedagang besar } \\
\text { (tidak langsung } \\
\text { peternak) }\end{array}$ & $\begin{array}{l}\text { Penanggungan } \\
\text { resiko, kelancaran } \\
\text { pembayaran, dan } \\
\text { upaya membagi } \\
\text { resiko ran } \\
\text { keuntungan antar } \\
\text { pelaku (lembaga } \\
\text { pemasaran) }\end{array}$ & $\begin{array}{l}\text { Networks, } \\
\text { norms of } \\
\text { reciprocity }\end{array}$ & $\begin{array}{l}\text { Terpelihara } \\
\text { Keberlanjutan } \\
\text { agribisnis }\end{array}$ \\
\hline
\end{tabular}




\begin{tabular}{|c|c|c|c|c|c|}
\hline $\begin{array}{l}\text { Luar } \\
\text { usahatani }\end{array}$ & $\begin{array}{l}\text { Pinjaman tunai } \\
\text { bunga }\end{array}$ & tanpa & $\begin{array}{l}\text { Pertukaran sumber } \\
\text { daya }\end{array}$ & $\begin{array}{l}\text { Networks, } \\
\text { norms of } \\
\text { reciprocity, } \\
\text { mutual trust }\end{array}$ & $\begin{array}{l}\text { Terpelihara } \\
\text { kemitraan usaha }\end{array}$ \\
\hline
\end{tabular}

Sumber: Data primer

\section{Simpulan}

Peranan social capital dalam memfasilitasi kerjasama antar pelaku (lembaga) agribisnis di lokasi studi pada umumnya didasarkan pada upaya melakukan pertukaran sumber daya (exchange of resources) yang dimiliki oleh masing-masing pelaku yang terlibat. Pertukaran sumber daya, sering dilakukan melalui keterpaduan aspek rasionalitas dan fleksibilitas. Aspek rasionalitas merupakan tuntutan dimensi ekonomi yang harus dilakukan guna menjaga keuntungan usaha, sedangkan aspek fleksibilitas merupakan tuntutan dari dimensi sosial supaya bisa saling memahami kondisi satu sama lain dalam melakukan hubungan bisnis. Dalam kaitan ini, social capital diwujudkan dalam bentuk penerapan norma-norma yang lebih lentur. Kedua aspek tersebut pada dasarnya ditujukan untuk menjaga keberlanjutan agribisnis jagung dalam jangka panjang.

Social capital pada hubungan petani dengan petani direpresentasikan dalam bentuk pertukaran tenaga kerja rumah tangga, sehingga bermanfaat dalam mengurangi biaya-biaya usahatani. Pertukaran tenaga kerja ini dikategorikan sebagai bentuk pertukaran yang sebanding dalam jangka pendek (strict and sort term reciprocity). Sementara itu, social capital pada hubungan petani dengan PPJ dan PPJ dengan pedagang besar pada prinsipnya juga didasarkan pada pertukaran sumber daya ekonomi yang dimiliki oleh masing-masing pelaku. Pertukaran sumber daya sering diwujudkan berupa penanggungan resiko, membagi resiko, dan menerapkan fleksibilitas dalam berbagai bentuk transaksi. Bentuk pertukaran tersebut dikategorikan sebagai pertukaran tidak sebanding dalam jangka pendek (non strict reciprocity in the short term). Secara tegas, kehadiran social capital dalam agribisnis jagung di lokasi studi memiliki peranan sebagai berikut: (a) penurunan biaya usahatani, (b) memfasilitasi terpenuhinya kebutuhan sarana produksi usahatani, (c) penurunan biaya monitoring, dan (d) terpeliharanya keberlanjutan dalam kemitraan usaha (keberlanjutan agribisnis).

\section{Daftar Pustaka}

Badan Pusat Statistik (BPS) (2013) Kecamatan tujuh belas dalam angka. BPS Kabupaten Bengkayang.

Damsar (2009) Pengantar sosiologi ekonomi. Cetakan Pertama. Jakarta: Kencana Prenada Media Group.

DFID (1999) Sustainable livelihoods guidence sheets. Department for International Development. [Diakses 20 Pebruari 2012]. http://www.eldis.org/vfile/upload/1/document/0901/section2.pdf.

Fukuyama F (1995) Trust: The social virtues and the creation of prosperity. New York: The Free Press.

Gunawan R, Thamrin J, dan Grijns M (1995) Dilema petani plasma pengalaman PIR-Bun Jawa Barat. Bandung: Yayasan Akatiga.

Pafchamps M \& Minten B (1999) Relationships and traders in Madagascar. The Journal of Developments Studies 35(6):1-35.

Subejo (2004) Peranan social capital dalam pembangunan ekonomi: suatu pengantar untuk studi social capital di pedesaan Indonesia. Jurnal Agro Ekonomi 11(1):77-86.

Subejo (2009) Characteristics and functions of labor institutions in rural Java: A case study in Yogyakarta Province. Journal of International Society for Southeast Asian Agricultural Sciencies (ISSAAS) 15(1):101-117. 
Syahyuti (2003) Bedah konsep kelembagaan, strategi pengembangan dan penerapannya dalam penelitian pertanian. Bogor: Pusat Penelitian dan Pengembangan Sosial Ekonomi Pertanian, Badan Penelitian dan Pengembangan Pertanian RI.

Syahyuti (2007) Dibutuhkan dukungan kebijakan untuk mengoptimalkan peran pedagang hasil-hasil pertanian. [Diakses 6 Januari 2010]. http://www.pse.litbang.deptan.go.id.

Syahyuti (2008) Peran modal sosial (social capital) dalam perdagangan hasil pertanian. Forum Penelitian Agro Ekonomi 26(1):32-43. 